\title{
SUPERNUMERARY NIPPLES IN A YOUNG MALE - A CASE REPORT
}

\section{General Surgery}

Kunal Kishor

Singh*

Anish Deepak
Baxla

Sushil Singh
Junior Resident Academic, Department of General Surgery, RIMS, Ranchi, Jharkhand, India. * Corresponding Author

Junior Resident Academic, Department of General Surgery, RIMS, Ranchi, Jharkhand, India

India

\section{ABSTRACT}

A 24 years old male presented with accessory nipples over lower part of chest for cosmetic reasons. On physical examination -2 supernumerary nipples were present, one on each side in inframammary region along the milk line without any associated symptoms or signs. The supernumerary nipples were surrounded by small areola and without any breast tissue. Rest of the general examination was within normal limits. No associated anomaly was found. There was no family history of accessory nipples. Ultrasound abdomen showed no renal malformations. Simple excision of supernumerary nipples was done with primary closure of the wound. Patient recovered uneventfully.

Polythelia results from the persistence of mammary ridges along the milk line which normally regress with development. The accessory breast tissue is of no physiologic significance but may undergo benign and malignant transformation like normal breast tissue. Hence, surgical excision is preferred in view of malignant potential.

\section{KEYWORDS}

Supernumerary Nipples, Polythelia, Male, breast cancer

\section{INTRODUCTION:}

Accessory breasts (Polymastia) or accessory nipples (Polythelia) may occur along the milk lines when normal regression fails and can be unilateral or bilateral. Normally, the milk line degenerates shortly after the development, leaving behind only a portion that persists in the pectoral region at the $4^{\text {th }}$ intercostal space, where the normal breasts develop.

The incidence of Polythelia varies from $0.2 \%$ to $5.6 \%$ in general population ${ }^{1}$. The most common site of accessory nipple is just below the normal breast and the most common site for accessory breast is in the lower axilla. It is extremely rare to find accessory breast tissue below the umbilicus ${ }^{2}$.Polythelia is more commonly seen in males than in females and is more common among blacks than in whites ${ }^{3,4}$.

Supernumerary nipples and breasts are physiologically non-functional but present as aesthetic complaints. They respond to hormonal changes in same way as normal breast tissue and may present with pain, lump or discharge etc. with fluctuation in hormones levels during puberty, menstruation, pregnancy or lactation. ${ }^{5}$

Polythelia is usually asymptomatic but may be associated with anomalies and malignancies of the urogenital tract. Here we report a case of supernumerary nipples in a young adult male without any specific complaints.

\section{Case report:}

A 24 years old male presented himself with cosmetic complains due to supernumerary nipples. He informed that the extra nipples were present since birth and he had no any related symptoms. There was no family history of accessory nipples or breast cancer. He did not have any history of urinary tract malformations.

On physical examination, the patient was a healthy 24 year male without any complaints other than cosmetic concern for the accessory nipples. There were 2 supernumerary nipples present, one on each side. On right side, the supernumerary nipple was present $10 \mathrm{~cm}$ below the main right nipple and on left side, the accessory nipple was present about $8 \mathrm{~cm}$ below the left main nipple in the inframammary region. Accessory nipples were about $15 \mathrm{~mm}$ x $20 \mathrm{~mm}$ in size and were present along the milk line. The accessory nipple were surrounded by small areola and no breast tissue. There was no signs of underlying swelling or pain on palpation. 
Routine laboratory investigations were within normal limit. Ultrasound of abdomen and pelvis was normal without any renal or genital abnormalities.

The patient underwent simple excision of accessory nipples with primary closure of wound along the Langer lines.

On follow up visit after 3 weeks, the patient had no complaints and has recovered well.

\section{DISCUSSION:}

Mammary glands are highly modified sweat glands, having an ectodermal origin. They develop from the two ventral bands of thickened ectodermal ridges (mammary ridges) which extend from the axilla to the inguinal region, during the 5 th or $6^{\text {th }}$ week of fetal development. Normally, the milk line degenerates shortly after the development, leaving behind only a portion that persists in the pectoral region at the 4th intercostal space, where the normal breasts develop. Failure of normal regression of mammary ridge results in the formation of accessory breast tissue along the milk line ${ }^{6}$. About $67 \%$ of the accessory breast tissue occurs along the abdominal and thoracic portions of the milk line and another $20 \%$ occur in the axilla. The remainder can present elsewhere along milk lines or other places.

The most common form of supernumerary breast tissue is polythelia. Polythelia is defined as the presence of accessory nipple with or without areola or accessory breast tissue. And Polymastia is defined as the presence of accessory breast tissue with or without areola and nipple. The prevalence of polythelia varies between 0.2 to $5.6 \%$, depending upon factors like sex, ethnicity, inheritance, and geographical area. Polythelia has more prevalence among blacks than whites and is more common in males.

The supernumerary nipples may occur in any size or configuration along the milk line. Usually, the accessory nipples are found just below the normal breast with less incidence in the infraumbilical and inguinal area. Various case reports have been published reporting the presence of accessory nipple and breast tissue over forearm ${ }^{7}$, thigh $^{8}$, face ${ }^{9}$, vulva $^{10}$, shoulder $^{11}$, perineum ${ }^{12}$ and foot ${ }^{13}$

The classification of accessory breast tissue established by Kajava ${ }^{14}$ in 1915 , still remains the universal system of differentiating the spectrum of presentation of accessory breast tissue:

KAJAVA Classification

\begin{tabular}{|l|l|l|}
\hline Type of Anomaly & Description & Terminology \\
\hline Type 1 & $\begin{array}{l}\text { Nipple }+ \text { Areola }+ \\
\text { Glandular tissue }\end{array}$ & Polymastia \\
\hline Type 2 & Nipple + Glandular tissue & - \\
\hline Type 3 & Areola + Glandular tissue & - \\
\hline Type 4 & Glandular Tissue & - \\
\hline Type 5 & Nipple + Areola & Pseudomamma \\
\hline Type 6 & Nipple & Polythelia \\
\hline Type 7 & Areola & Polythelia Areolaris \\
\hline Type 8 & Patch of Hair & Polythelia pilosa \\
\hline
\end{tabular}

Most cases of supernumerary nipples occur sporadically but familial cases have also been reported, including one report of a family who had accessory nipples present in up to 4 generations. Specific mutations are not known for either. The inheritance pattern in familial cases follows an autosomal dominant fashion with incomplete penetrance and a dominant $\mathrm{X}$ linked chromosome $\mathrm{e}^{15}$

Supernumerary nipples are found as a part of various syndromes ${ }^{16}$ like Turner's syndrome, Fanconi anemia, Simpson- Galabi -Behmel syndrome, Char syndrome, Foetal alcohol syndrome etc.

Several studies have shown associations between polythelia and genitourinary malformations $\mathrm{s}^{17}$ and malignancies that occur in about 23 - $27 \%$ cases of Polythelia. Supernumerary kidneys, renal aplasia, hydronephrosis, polycystic kidney disease, duplicated renal arteries, ureteric stenosis are commonly associated with polythelia. Some studies have demonstrated a higher incidence of renal anomalies in patients with supernumerary nipples, the prevalence of which was about three times greater than expected ${ }^{18}$. In a study by Urbani \& Betti, they found ipsilaterality of the renal anomalies and supernumerary nipple in a patient with renal adenocarcinoma, further supporting an embryonic origin of the malignancy ${ }^{19}$. The probable reason for the association between polythelia and urogenital anomalies being that both the regression of the milk line and development of the urogenital system starts around 3rd to 4th month of gestational age. Polythelia is also associated with $19 \%$ of patient with renal adenocarcinoma and $16.5 \%$ of patients of end-stage renal disease. ${ }^{20}$

Polythelia is also associated with malformations of the cardiac, vertebral, and central nervous system. It is also associated with carcinoma of the breast and testicular carcinomas. In a study by Goedert et al it was estimated the risk of testicular cancer in men with polythelia to be 4.5 times greater than men without an accessory nipple

Polythelia is generally recognized at birth, but it may be confused with nevi, warts, or other skin lesions. Polymastia may not be evident until puberty when physiologic changes occur due to hormones. Accessory nipples and breasts are prone to similar benign and malignant pathologies like normal breast tissues and should be taken seriously. Incidence of malignancy in accessory breast tissues varies between 0.2 - $0.6 \%$, with the invasive ductal carcinoma being the most common histologic type.

In the majority of patients, the extra nipples are benign and never produce symptoms. But if any symptoms develop like a lump, discharge, etc., it should be thoroughly investigated as polythelia is a potential marker for malignancy and malformations. All cases of polythelia should be evaluated for genitourinary malformations and malignancies and other malignancies.

Surgery is currently suggested in cases of suspected malignancy, symptomatic cases, and for cosmetic reasons. Surgical removal of accessory nipples in females should be done before puberty to avoid wider tissue excision owing to glandular growth. And surgical treatment of polythelia in males should be done if there is any symptom suspicious of malignancy.

\section{CONCLUSION:}

Polythelia is the most common form of accessory breast tissue and is more common in males. All cases of polythelia should be investigated and evaluated to rule out genitourinary or other malformations or malignancy. Surgical treatment should be performed if there is a concern for malignancy or cosmetic concern is present.

\section{REFERENCES:}

[1] Schmidt H. Supernumerary nipples: prevalence, size, sex and side predilection prospective clinical study. Eur J Pediatr 1998;157: 821-3

[2]. Dixon JM, Mansel RE. ABC of breast diseases. Congenital problems and aberrations of normal breast development and involution. BMJ 1994;309:797-800.

[3] Stone K, Wheeler A. A review of Anatomy, physiology, and Benign Pathology of the Nipple. Ann Surg Oncol. 2015;22:3236-3240.

[4] Rahbar F. Clinical significance of supernumerary nipples in black neonates. Clin Pediatr. 1982;21:46-7

[5] V. Velanovich, "Ectopic breast tissue, supernumerary breasts, and supernumerary nipples," Southern Medical Journal, vol. 88, no. 9, pp. 903-906, 1995.

[6] Moore KL, Persaud TV. The integumentary system. In: Moore KL, Persaud TVN, editors. The Developing Human: Clinically Oriented Embryology. 5th ed. Philadelphia: W.B. Saunders Co; 1998. p. 513-30.

[7] Tauchen, Alexander \& Kueberuwa, Essie \& Schiffman, Kenneth \& Mudaliar, Kumaran \& Noland, Shelley. (2015). A Rare Case of a 15-Year-Old Boy with Two Accessory Nipples: One in the Forearm and One in the Milk Line. Case Reports in Surgery. 2015.13. $10.1155 / 2015 / 752479$

[8] C. Camisa, "Accessory breast on the posterior thigh of a man," Journal of the American Academy of Dermatology, vol. 3, no. 5, pp. 467-469, 1980.

[9] U. Koltuksuz and E.Aydin, "Supernumerary breast tissue: a case of pseudomamma on the face," Journal of Pediatric Surgery, vol. 32, no. 9, pp. 1377-1378, 1997.

[10] R. L. Guerry and H. R. Pratt-Thomas, "Carcinoma of supernumerary breast of vulva with bilateral mammary cancer," Cancer, vol. 38, no. 6, pp. 2570-2574, 1976.

[11] M. Schewach-Millet and B. K. Fisher "Supernumerary nipple on the shoulder," Cutis, M. Schewach-Millet and B. K. Fishe
vol. 17, no. 2, pp. 384-385, 1976.

[12] S. Basu, T. Bag, K. S. Saha, and P. C. Biswas, "Accessory breast in the perineum," Tropical Doctor, vol. 33, no. 4, article 245, 2003

[13] D. M. Conde, E. Kashimoto, R. Z. Torresan, andM. Alvarenga,"Pseudomamma on the foot: an unusual presentation of supernumerary breast tissue," Dermatology Online Journal, vol. 12, article 7,2006.

[14] Kajava Y. The proportions of supernumerary nipples in the Finnish population. Duodecim $1915 ; 1: 143-70$

[15] Fonseca GM, Cantin M. Polythelia family associated with dental anomalies: a case report. Colomb Med. 2014:45(1):45-47.

[16] Grimshaw EC, Cohen PR. Supernumerary nipple and seminoma: Case report and review of polythelia and genitourinary cancers. Dermatol Online J 2013;19:4

[17] V. Meggyessy and K. M'ehes, "Association of supernumerary nipples with renal anomalies," The Journal of Pediatrics, vol. 111, no. 3, pp. 412-413, 1987

[18] Gauthier B: Supernumerary nipples and urinary tract anomalies [letter]. J Pediat 1988;112:503-503

[19] Urbani CE, Betti R: Aberrant mammary tissue and nephrourinary malignancy: a man with unilateral polythelia and ipsilateral renal adenocarcinoma associated with polycystic kidney disease. Cancer Genet Cytogenet 1996;87:88-89.

[20] High Incidence of Supernumerary Nipples in End-Stage Renal Failure R. Matesanz, J.L. Teruel, F. Garcia Marlin, Nephron 44: 385-386(1987).

[21] Goedert JJ, McKeen EA, Javadpour N, Ozols RF, Pottern LM, Fraumeni JF Jr: Polythelia and testicular cancer. Ann Intern Med 1984;101:646-647.

[22] Nihon YY, Ueda T. A case of ectopic breast cancer with literature review. Surg Onco 2011:20:35-42. 